\title{
THE DIALOGUE BETWEEN SOLOIST AND ORCHESTRA WITHIN THE CONCERTO PRESENTED THROUGH PEIRCE'S "THEORY OF SIGNS"
}

\author{
UDC [785.6+78.087.1]: 781.1 Peirce's "Theory of Signs"
}

\section{Neda Nikolić}

University of Niš, Faculty of Arts in Niš, Serbia

\begin{abstract}
The dichotomy between individualism and collectivism, deeply rooted in the development of social life, reflects an anthropological aspect that is also reflected in the art of music. This opposition, which is manifested through the relationship between the soloist and the orchestra within the concerto, is one of its main genre features. It survives despite all the changes that have taken place throughout history, but it is still subject to modifications. However, the role of these entities, apart from the style of the epoch, was also influenced by the composer's personal style which must also be taken into account when considering the work from any point of view. The proposal to apply the method of Charles Peirce's "Theory of Signs" is to help to elucidate the meanings that this type of dialogue produces and which are hierarchically arranged and positioned within the pyramidal structure. Accordingly, the theme of the paper aims at showing the relationship between the soloist and the orchestra, showing what their function is within the concerto, as well as how their roles have changed throughout the change of epochs in history and the meaning this type of dialogue conveys.
\end{abstract}

Key words: concerto, soloist, orchestra, dialogue, Peirce's "Theory of Signs "

\section{INTRODUCTION}

If one looks at the development of primitive communities and their evolution through different historical periods until today, one will come to know that the relationship between the individual and the collective is a fundamental dimension by which societies differ. The dichotomy between individualism and collectivism, deeply rooted in the development of social life, reflects an anthropological aspect that is also reflected in the

Received April 12, 2021 / Accepted May 11, 2021

Corresponding author: Neda Nikolić

University of Niš, Faculty of Arts in Niš, Kneginje Ljubice 10, 18000 Niš, Serbia

E-mail: nikolic.neda95@gmail.com 
art of music. This opposition, which is manifested through the relationship between the soloist and the orchestra within the concerto, is one of its main genre features.

Accordingly, the theme of the paper has the aim to show the relationship between soloist and orchestra, to show what their function is within the concerto, how their roles have changed through the change of epochs in history and what meaning this type of dialogue generates, as indicated by the chapter titles who consider each segment of the theme separately (individualism versus collectivism, tutti-solo through the centuries, the function of soloist and orchestra in concerto, the meaning of dialogue as described by Charles Sanders Peirce's "Theory of Signs"). The signification of the opposition will prove very important for the production of meaning that shows the anthropomorphic expression of a balance, which is based on contrast, but whose elements together establish the balance. This way of perceiving the binary opposition individualism collectivism can be methodologically presented through the cognitive theory of Candace Brower based on the schemes of bodily experience. However, in musical discourse, the meaning of the antithesis between soloist and orchestra will be presented through the analytical-interpretive "Theory of Signs" by Charles Peirce, which will serve as a methodological proposal for defining signs and showing the functions that different types of signs acquire within the concerto.

\section{INDIVIDUALISM VERSUS COLLECTIVISM}

Certain animal species live in packs, while others live alone. This type of existential experience has also been reflected by the human species since the beginning of the primitive communities, and this principle was adopted as a foundation for the conception of all social activities and the way social groups function both in the past and today. If you look at a wide range of human groups, different habits of people such as living in a group, within a wider or immediate family, within tribal communities or leading an individual life can be seen (Hofstede 2001, 209-210). Thus, "in human life and history there is no more ancient and universal experience than the antithesis of the individual and the crowd" (Keefe 2005, 13), that is, "the fundamental dimension on which societies differ is formed: the relationship between the individual and the collectivity" (Hofstede 2001, 210). This structures the anthropological expression of a balance - it is based on contrast, but together they establish a balance. "Individualism and collectivism are not opposites, just as women are not opposites to men. They are complementary constructions, and understanding one helps to understand the other. Consequently, it is difficult to find a purely individualistic or collectivist culture on the cultural level, given that cultures are often found to have elements of both of these constructions."1

As Triandis (Harry Charalambos Triandis) states, individualists function independently of the group, have their own independent goals and emphasize the presence of rationality in the creation of their social relations as their main character trait. In contrast, collectivists function by adapting to other people in the group, their goals are compatible with groups, their social behaviors are guided by norms and they are relative in social exchange with other people. Self-awareness from an individualist perspective does not include other people, that is, the Self is independent of others, while self-awareness from a collectivist

\footnotetext{
${ }^{1}$ Dharm P. S. Bhawuk, Individualism and Collectivism, Wiley Online Library, 2017 https://onlinelibrary.wiley. com/doi/full/10.1002/9781118783665.ieicc0107, accessed 05.09.2020. at 19:15
} 
perspective includes other people, namely family members, friends and people from the workplace. ${ }^{2}$

This way of perceiving the binary opposition individualism-collectivism can also be presented through the cognitive theory of Candace Brower on the basis of patterns of bodily experience that exemplify space, time, force and movement (Brower 2000). Based on this theory, an individual or a collective will be aware of their body and position in a space bordered by an outline that divides the territory into internal and external parts. This type of individualism and collectivism can be interpreted in two ways: an individual space enclosed by the collective or, conversely, a collective space bordered in relation to the individual (Fig. 1).

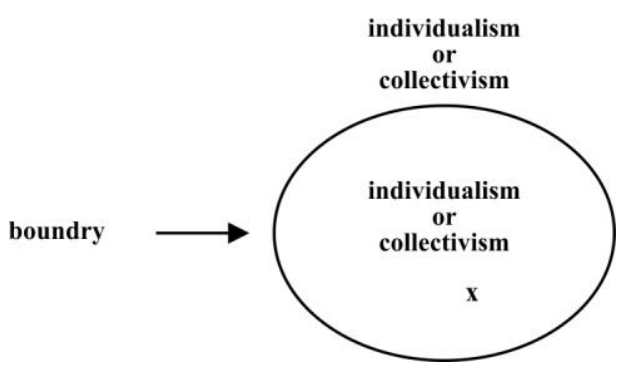

Fig. 1 Representation of individualism and collectivism through the CONTAINER scheme taken from Candace Brower with modifications (Brower 2000, 328)

On the other hand, another scheme for individualism and collectivism that "reflects the alternation of processes or states related by binary opposition can be applied: up versus down, tension versus relaxation, in versus out, departure versus return. Thus, maintaining a consistent relationship between stability and tension is important for the use of the center-verticality-balance scheme" (Brower 2000, 330). In order to establish balance within the already mentioned dichotomy, this scheme can be applied, because in one of the two constituents, tension or relaxation will prevail, and in the other, the opposition element. Although these mental schemes provide orientation in listening to music, they can also significantly contribute to the understanding of the collective and individual aspect of society, as well as the way it functions (Fig. 2).

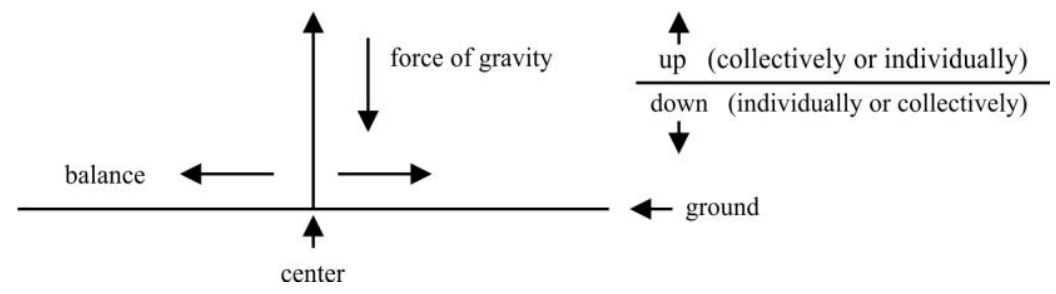

Fig. 2 Representation of individualism and collectivism through the center-verticality balance scheme taken from Candace Brower with modifications (Brower 2000, 330)

\footnotetext{
${ }^{2}$ The same.
} 
This dichotomy, which is deeply rooted in the conception of society, has the function of a kind of thread that transcends all time constraints and survives despite all the changes that have taken place throughout history. For this dichotomy, it is not only important that it is based on the individual-collective contrast, but also on the fact that its functioning and organization are influenced by social norms and constrains that prevail over a given time. Accordingly, it is necessary to take into account the various institutions and the ways in which they are organized in order to gain a complete insight into the discourse that influences the conception of opposition elements (Hofstede 2001, 210). "This is indicated by the fact that certain changes in life habits are noticeable in different types of societies (hunting, agricultural societies, and so on)" (Ibid., 210). This is a consequence of contemporary modern industrial society which redirects the state of development and thus contributes to a fast way of life and because of that people disintegrate into immediate families. Life in a collective, as well as the life of an individual, is reflected in the art of music. We will explain that in the further course of the paper.

\section{TUTTI-SOLO THROUGH THE CENTURIES}

The anthropological aspect based on the opposition individual - society, which is deeply rooted in folklore and the life of the people, can be seen in everyday life, from the primitive social communities to the present day ones. This is reflected in all aspects of life and music.

If we look at the development of the primitive social communities, it can be noticed that the people who were engaged in hunting showed individual musical expression, while the people who were engaged in agriculture were characterized by collective performance of music. In the Paleolithic, music did not exist as an independent category, but singing existed as an integral part of certain life processes. At the core of early music, collective activity stood out, while later "soloists" stood out. As time went by, the polarization individually-collectively reflected on the art of music and led to the fact that it could be noticed within the concerto genre. This interaction, which is manifested through the change of soloist and orchestra, is one of its main genre characteristics (as well as in the genres of vocal music in which there is responsorial singing, antiphonal singing and so on). This is also shown by the definition of "The New Grove Dictionary of Music and Musicians" for the term concert: "it is an instrumental work that maintains contrast between an orchestral ensemble and a smaller group or a solo instrument, or among various groups of an undivided orchestra." 3 If we look at the origin of the word "which derived from the Latin concertare and which signifies competition, discussion" it can be noticed that the etymology of the term describes precisely this dichotomy.

On the other hand, 'through the history the word 'concert' came into use in the 17th and 18th centuries to denote contexts where people performed music together. Until the middle of the 19th century, 'concert' could mean either private or public occasion, in a home or in a hall. Wolfgang Amadeus Mozart, for example, often spoke of a 'Konzert' in his letters to describe evenings of informal, domestic music-making where all present were performers. Since about 1840 the term has been used only for public and non-theatrical events, but in a wide variety of

\footnotetext{
${ }^{3}$ Arthur Hutchings/r, Michael Talbot, Cliff Eisen, Leon Botstein, Paul Griffiths, Concerto, in: Laura Macy (ed.), Grove Music Online, http://www. oxfordmusiconline.com/grovemusic, accessed 11.05.2021. at 10:10

${ }^{4}$ William Weber, Concert (ii)., in: Laura Macy (ed.), Grove Music Online, http://www. oxfordmusiconline.com/ grovemusic, accessed 03.09.2020. at 15:05
} 
contexts, either formal or informal. In the middle of the 20th century the term was extended to presentations of jazz, rock and popular music generally." 5

If we go back to the term "concerto", the origin of this word means competition, discussion. This is symbolically depicted by a separate setting of the protagonists on the stage, the competition of soloists with the orchestra represents an anthropomorphic element thanks to a competitive type of interaction ${ }^{6}$ or represents their complementarity. The duality between the protagonists also reflects subjectivity, the struggle of the individual against the collective, the outside world. On the other hand, the concerto can be approached from another perspective, which views the orchestra as a group of individuals where each has its own personal expression (Elliott Carter) (Keefe 2005, 13). Thus, the basic anthropological opposition, as the foundation of existential experience, became the basis for the concerto, which proved to be flexible and suitable for exploring and emphasizing the duality between soloist and group of instruments, i.e. between individualism and collectivism.

The relationship between the soloist and the orchestra is very often connected with the ancient tragedy with Koch (Heinrich Christoph Koch), i.e. with the drama precisely because of the presence of interaction between the protagonists, as it is compared to the narrative (Ibid., 13-14). The solo-orchestra interaction is dramatic in nature for Donald Tovey, as the concerto itself is "a highly dramatic and poetic art form. The solo should first be inclined to enter into dialogue with the orchestra - the speaker should conciliate the crowd before the he breaks into monologue" (Ibid., 13).

Although the concerto is par excellence a form for showing the relationship between the soloist and the orchestra, it is also suitable for exploring social and musical events (Ibid., 19). By definition, "a modern concert makes music the center of social attention. This was an innovation, because until the 17th century, it was assumed that music accompanied other social activities, because simply listening to music, formally and regularly, was unusual. A concert is therefore significantly different from ceremonies or services and from entertainment in which the role of music is secondary". ${ }^{7}$ It is shaped by social influences and represents a medium for researching the social aspect, value norms, that is, it is suitable for researching the entire spirit of the time because the features of the concert always reflected the taste of the zeitgeist of that time (Keefe 2005, 19). "The New Grove Dictionary of Music and Musicians" also writes about this, stating that the concert developed from informal occasions when music coexisted with other social activities. Courts offered music after dinner, taverns sponsored musicians in their spaces, and cathedrals presented works by original composers in services where music was present. Concerts arose from such performing traditions in a gradual process during the 17 th and early 18 th centuries. Although the performance followed the service, it

\footnotetext{
5 The same.

6 Johann Gottfried Walther speaks of the 'rivalry' between concerto protagonists and Augustus Frederick Christopher Kollmann (1799) suggests that the concerto is capable of representing the kind of confrontation witnessed in C. P. E. Bach's famous trio sonata, 'A Conversation between a Cheerful Man and a Melancholy Man'. Other eighteenth-century critics, in contrast, paint pictures of collaboration, Johann Joachim Quantz (1752) explaining that each orchestral participant 'must regulate himself in all cases by the execution of the soloist, . . . always do his share' and yield to the soloist's tempo when he or she 'gives a sign to that effect'. (Keefe 2005, 10)

${ }^{7}$ William Weber, Concert (ii)., in: Laura Macy (ed.), Grove Music Online, http://www. oxfordmusiconline.com/ grovemusic, accessed 03.09.2020. at 15:05
} 
was defined as a separate event and until 1700 the choir and orchestra were sometimes involved. ${ }^{8}$

The individualistic attitude towards music completely exposed all musical forms, including court and chamber music. On the one hand, with the increase in the number of both concert audiences and performers, the first signs of a split between orchestral and chamber music appeared. Many instrumental works from the second half of the seventeenth century could still be performed either individually or collectively, by several instruments. However, during this century, more and more music was actually based on the change of soloist and orchestra, thus preparing the way for numerous concerto forms (Abraham 1986, 377-378).

Accordingly, if we look at the development of the concerto, which is based on a conversation between two performing bodies and which is an important genre trait given that this dichotomy extends from ancient times to the present day, regardless of changes in history, can be noticed that two stylistically different types of concerto were formed, the Baroque and the Classical concerto. The Baroque concerto is characterized by the stylistic complex concerto grosso, which is based on the competition of a smaller group of instruments (concerto) with a larger group. This later led to the development of a solo concerto from a concerto grosso which meant the highlighting of one solo instrument, not more than one. The solo concerto, developed in the eighteenth century and based on the interaction of the soloist/s with the orchestra it provides space for the emphasis on technical skills. ${ }^{9}$ However, "the strict division between the soloist, orchestra player and leader was not necessarily what late eighteenth and early nineteenth-century composers had in mind" (Campbell 2009, 1).

In the eighteenth century, the dialogue between the soloist and the orchestra was conceived in such a way that, in addition to emphasizing the interaction, it was important to emphasize the virtuosity of the protagonist. For that reason, writers at the end of the eighteenth and nineteenth centuries very often equated the participants in the dialogue with acrobats and their tricks in order to further emphasize the dynamism that the form of the concerto contains in its basis through comparison (Keefe 2005, 8). "Two of the earliest writers on the concerto form, Johann Joachim Quantz (1752) and Joseph Riepel (1755), encourage judicious inclusion of small-scale tuttis in solo sections - as well as describing large-scale ritornello-solo alternation - thus implicity aknowledging lively solo-orchestra interaction" (Ibid., 16).

Although the concept of 'concerto' changed in the nineteenth century due to the tendency for the concerto to take on symphonic dimensions, it still depended on the conversation between the soloist and the orchestra (Ibid., 10). During this period, it was also important to emphasize virtuosity, which was always an integral part of the concerto, but which in the 19th century also had to do with the concept of genius. However, in this discourse, technical ability had indications to surpass other musical components. It is this compositional-technical aspect that was criticized both in the nineteenth and later, in the twentieth century. "On the whole, however, recent scholarship is marked by a greater receptivity to the aesthetic virtues of virtuosity than in earlier scholarly eras. A good case in point is Joseph Kerman's careful broadening of the concept to include virtu', with its constituent bravura, mimetic and

\footnotetext{
${ }^{8}$ The same.

${ }^{9}$ Arthur Hutchings/r, Michael Talbot, Cliff Eisen, Leon Botstein, Paul Griffiths, Concerto, in: Laura Macy (ed.), Grove Music Online, http://www.oxfordmusiconline.com/grovemusic, accessed 11.05.2021. at 10:10
} 
spontaneous qualities" (Ibid., 11). In addition to virtuosity, the emphasis was placed on the symphonic dimension of the work, which was developed in the twentieth century (Ibid., 11).

The differentiation of the soloist/s from the orchestra, with the help of which the contrast and conflict are emphasized, as well as the mutual complementarity, survives and remains a genre feature within the concerto that is also connected with social significance. This is explained by Nicky Losseff's explanation of the broad musical and social significance of confrontation and opposition in concerto, which is supported and supported by a long tradition based on interaction and explained through anthropomorphism in the twentieth century (Ibid., 12-13).

As Quanz and Ripel described the interaction between the protagonists in an eighteenthcentury concerto, their role was taken over by Tovey and Rosen who described an identical situation in the twentieth century. This procedure shows that the relationship between soloists and groups exceeds all time limits and exists in the most diverse contexts, receiving and absorbing the characteristics that the spirit of time of different epochs brings along. Accordingly, this surviving dialogue is subject to change depending on the context, that is, the relationship between soloists and groups changes accordingly. Similar to eighteenth and nineteenth-century writers, these two authors draw attention to the interdependence of the form and interaction of soloists and orchestra and their relationship (Ibid., 17). "Tovey explains that the first movement arrangement of an opening ritornello section for the orchestra followed by a section higlighting the soloist is musically and affectively intuitive, since it brings out the force of the solo in thrusting the orchestra into the background" (Ibid., 17).

The opposition between the soloist and the orchestra has primarily the function of emphasizing the dialogue in music and it has been manifested from the primitive communities until today. The applicability of this element in music, as well as the manifestation of virtuosity characteristic of the concerto, shows the reconstruction of past performance practices. It was realized thanks to the knowledge of Baroque conventions and tastes of the audience which revealed the intellectual and artistic potential of music and which contributed to a better understanding of the context with the possibility of following the modifications that occurred over time, i.e. the possibility of monitoring the dialogue between soloists (Ibid., 226). What their function was in the concerto and in what way the soloist and the orchestra had different roles depending on the epoch in which they manifested themselves, will be explained in the next segment of the paper.

\section{FUNCTION OF SOLOIST AND ORCHESTRA IN CONCERTO}

"The explicit use of 'concerto' as a title is not in itself evidence of a conservative disposition: composers are just as likely to employ it to dramatize the distance of their own concepts from those of tradition as to suggest strong sympathy with that tradition" (Ibid., 162). The dialogue between the protagonists has become the focus of controversial topics such as the interaction between the soloist and the orchestra and the perception of the function of the orchestral accompaniment and the nature of the music assigned to the soloists. "Theoretical and critical debate on these topics influences and is influenced by compositional practice, thus making a highly significant contribution to the continued vitality, transformability and popularity of the concerto genre" (Ibid., 7).

As already mentioned, the dichotomy exemplifies the form of the concerto, and the functions of the elements that form the opposition pair can be traced back to the creation 
of Antonio Vivaldi's Italian concerto. In this context, textural and thematic differentiation is achieved by virtuoso demands placed on the soloist/s. On the other hand, Johann Sebastian Bach did not accept this dichotomy as a necessary feature of the genre and instead continuously sought integration between solo and tutti elements and their close exchange of materials (Ibid., 56). In relation to Vivaldi and Bach, C. P. E. Bach's attitude towards dialogue was such that the soloists were given episodes of long duration in shifts with relatively unobtrusive comments by the orchestra (Ibid., 67). Apart from composers, an author like Donald Tovey took a similar view on the treatment of tuttis, who believed that "tuttis do not function exclusively, or even primarily, as structural pillars around which concerto movements are built, but as contrasting sonorities."10

Since the role of these entities depends on the musical discourse in which it manifests itself, the soloist on keyboard instruments has the function of performing a continuo in the tuttis and the function of the soloist outside the tuttis. ${ }^{11}$ Apart from the style of the epoch, the role of the elements is also influenced by the personal style of the composer. Mozart's concertos can be an example in which Koch recognizes three functions of a soloist: "within the large solo sections of his concertos, orchestral outbursts are often accompanied by a soloistic continuo that does not literally duplicate the orchestral basses, projecting a solo personality even in these apparently accompanimental sections. In this respect Mozart's works look forward to concerto styles of the nineteenth century where continuo function disappears." 12 Taking into account the treatment of protagonists in the seventeenth and eighteenth centuries, it can be concluded that the element that connects the Baroque and Classical concerto is the treatment of a soloist who did not "rest" during the orchestral performance and it is a practice that included all solo instruments which were current in that period. In contrast to this principle, which was dominant in the seventeenth and eighteenth centuries, the practice of performing was changed in the nineteenth century. It is reflected in the "pausing" of soloists while orchestral tuttis last.

The roles of the protagonists, as already mentioned, are connected with the dialogue in this period (18th and 19th century), but also in general, so the form of the concerto can be interpreted as a narrative within which the orchestra tells the story. In it, as in sonata form, the opening orchestral segment exhibits the initial material, the solo segment contrasting material, so that versions of their stories are synthesized at the very end, which is analogous to the exposition, development and reprise (Keefe 2005, 18). "The rich hermeneutic potential that derives from the synergy of form and interaction in the Classical concerto - and from analogous synergies in earlier and later works as well will no doubt provide enlightening and provocative interpretations of concertos" (Ibid., 18). However, in 1847, the theorist Adolf Bernhard Marx considered that the form of a concerto no longer differed from the sonata form. Tutti/solo alternation is now just a matter of orchestration, not structure (Ibid., 101). Marx is, as Jane Stevens writes, the first to understand "the solo and orchestra solely as cooperative elements working out a single, symphonic form, with the opening tutti performing a merely introductory and decidedly subservient, role" (Ibid., 101).

Analogous to Koch's interpretation, which states what the roles of the orchestra and soloist were in the context of an eighteenth-century concerto, and on the example of

\footnotetext{
${ }^{10}$ Cliff Eisen, The Classical period, in: Laura Macy (ed.), Grove Music Online, http://www. oxfordmusiconline. com/grovemusic, accessed 03.09.2020. at 18:20

${ }^{11}$ The same.

${ }^{12}$ The same.
} 
Mozart's concertos, Pyotr Ilyich Tchaikovsky presents an uncompromising interpretation of the solo-orchestra opposition in a nineteenth-century piano concerto. Considering that the tone of the piano makes it impossible to merge with the tone of the orchestra, he identifies that the piano can be effective in only three situations: (1) alone, (2) in contrast to the orchestra, (3) as an accompaniment or background of the image (Ibid., 11).

Unlike the practice of the nineteenth century, the kind of discourse that is central to eighteenth-century concertos based on the exchange of material between protagonists and one of the main features of late seventeenth and eighteenth-century concertos, manifests itself in the twentieth century. "The essence of the concerto, that of a soloist playing with an ensemble, was one of the 20th century's most inexpugnable inheritances." 13 The practice of joining the solo piano section to the segments in which the orchestra performs is already noticeable with Igor Fyodorovich Stravinsky. This tendency towards concertos in which equality between soloist and orchestra is now manifested, is noticeable, apart from Stravinsky's compositions, in Anton Webern's compositions, within the concerto genre which provided solo opportunities for each section (J. S. Bach's Brandenburg Concertos No. 1 and No. 3). A significant feature of the concertos after the Second World War was based on the dramatic conception of the relationship between soloists and ensembles, with each side depicting "characters". They form a peaceful dialogue, lively discussion or independent development. However, in the 1970s, the word "concerto" lost all residual formal meaning and was used to denote a piece with one or more soloists. Many other composers in this period even stopped using the name "concerto" and found other names for concerto works that have little in common with concertos of earlier periods (some of such examples are Stravinsky's "Movements for Piano and Orchestra" (1958-9), Messiaen's many pieces for piano and ensemble, Boulez's work "Domaines" for clarinet and six instrumental groups (1961-8), and so on). ${ }^{14}$

\section{THE MEANING OF THE DIALOGUE SHOWN THROUGH PEIRCE'S “THEORY OF SIGNS”}

By considering all the characteristics and modifications of the concerto dialogue through the centuries, a hierarchy of universal elements that form a kind of pyramidal structure can be implemented. It can be represented by Peirce's typology of signs as follows (see Fig. 3):

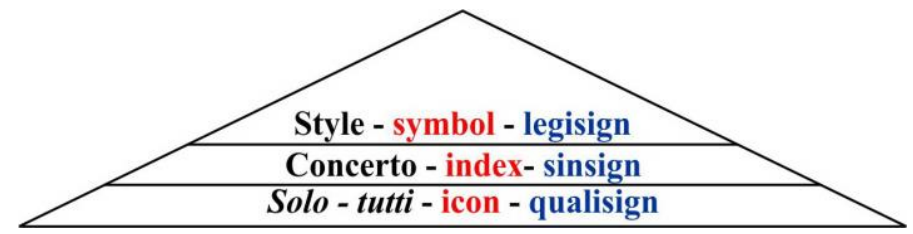

Fig. 3 The hierarchy of elements influencing the conception of the concerto presented through a pyramidal structure

\footnotetext{
${ }^{13}$ Paul Griffiths, The 20th century., in: Laura Macy (ed.), Grove Music Online, http://www. oxfordmusiconline.com/ grovemusic, accessed 03.09.2020. at 15:05

${ }^{14}$ The same.
} 
The interaction between the soloist and the tutti, i. e. the orchestra, in addition to having its roots in the primitive social communities, also depicts the universal existence between the individual and the collective, and its reflection on musical discourse is exemplified through the concerto. Using Peirce's "Theory of Signs" (Short 2007), the relationship between soloist and orchestra can be called a qualisign representing the concerto (as well as responsorial and antiphonal singing). As the solo and tutti segments are picturesquely indicated in the score, which faithfully depicts their differentiation, in the same way this dialogue is shown on the stage, which is reflected in the clear separation of the soloist and the orchestra. Accordingly, the solo-tutti relationship acquired the status of an icon precisely because of the similarity between the sign and the object.

Qualisign, i. e. icon, is a genre feature of the concerto, which is therefore at a higher hierarchical level in relation to the solo-tutti dialogue. For this reason, the concerto assumes the function of an index, which "is a sign which refers to the Object that it denotes by virtue of being really affected by that Object on the fact that that object is actually under the influence of the object" (Monelle 1992, 198). Without the presence of interaction between the protagonists, the concerto would not have been identified. In accordance with the presented chronology, the solo-tutti represents a qualisign sign or a token of the type, which is represented by the concerto.

The qualisign, which refers to the dichotomy of solo-tutti, the sinsign, which denotes a concerto, function thanks to the norms, constrains and universals of the style or spirit of the time. It has acquired the status of a symbol defined as "a Representative character consists precisely in its being a rule" (Monelle 1992, 199). "The symbol is dependent on an agreed or cultural nexus" (Monelle 1992, 199), which gives the style the status of a legisign.

In accordance with the application of Peirce's "Theory of Signs", two relations between three different levels can be observed. Qualisign, or solo-tutti, is a token of the type, which is a sinsign and signifies the concerto. In addition to this connection, the token-type relationship can also be identified between the sinsign and the legisign, i.e. style, as a regulator of the pyramidal structure. Accordingly, the double relationship between different levels defines the hierarchy between the characters and positions the style as a mechanism that directs events to the other two levels, and the relationship between soloist and orchestra stands out as an indispensable element for the formation and survival of the concerto (Fig. 4).

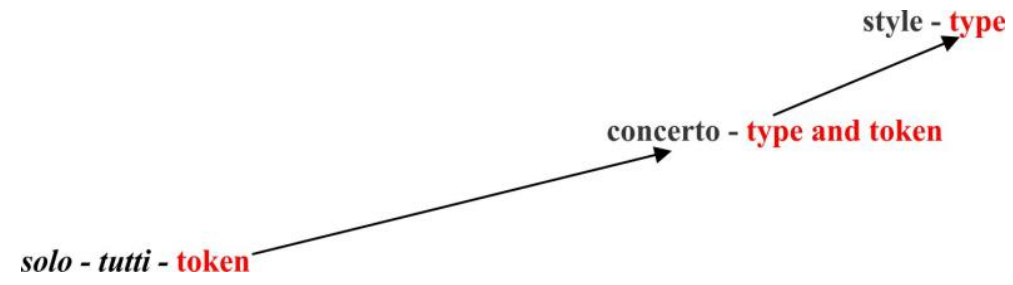

Fig. 4 Representation of the double relation between different hierarchical levels

\section{CONCLUSION}

The development of a dialogue between the individual and the collective, i.e. between the soloist and the orchestra, has the function of a kind of genre line that survives despite all the changes that have taken place throughout history, but which is still subject to 
modifications. Its functioning is influenced by the norms and constrains of the spirit of the time, which intersect the time continuum, forming smaller temporal wholes, i.e. historical epochs. During the review of the historical cross-section, one could notice the development, as well as the changes that took place within the epochs and which were reflected in the concept of the concerto, i.e. in the dialogue between the soloist and the orchestra. Thus, the opposition between the protagonists became the focus of controversial topics such as the interaction between the soloist and the orchestra and the perception of the function of the orchestral accompaniment and the nature of the music assigned to the soloists. Since the role of these entities depends on the musical discourse in which it manifests, the soloist mainly had the function of performing a continuo in tutti and the function of a soloist outside of tutti. However, their function changed depending on the epoch, which is indicated by the fact that soloists in the nineteenth century were important in emphasizing virtuosity and overcoming other musical components. After all the modifications, the essence of the concerto in the 20th century lies in the legacy from previous centuries, which refers to the alternating performances of the soloist and the ensemble. It is also true that in the first half of the 20th century equality between the soloist and the orchestra was manifested, with each section being provided with solo opportunities. After the Second World War, there was a current dramatic conception of the relationship between a soloist and an ensemble, while in the 1970s the word "concerto" was used to denote a work with one or more soloists. However, in addition to the style of the epoch, the role of the entity was also influenced by the personal style of the composer, which must also be taken into account when considering the work from any point of view.

The proposal to apply the Charles Peirce's method of "Theory of Signs" helped to elucidate the meanings that this type of dialogue produces and which are hierarchically arranged and positioned within the pyramidal structure. Thanks to Peirce's analyticalinterpretive model, two relations were formed between three different levels that set the style (legisign) at the top of the pyramid as a kind of regulator for the concerto (sinsign), or for dialogue between soloist and orchestra (qualisign). This shows that the interaction between the soloist and the orchestra, which has survived throughout the centuries, is still subject to change and that depends of the context. The relationship between the soloist and the orchestra changes accordingly, which is indicated by the fusion of genres such as chamber-concerto, concerto-symphonic and chamber-symphonic works.

\section{REFERENCES}

Abraham, G., (1986), The New Oxford history of music. Vol. 6, Concert music: (1630-1750), Oxford University Press, London.

Brower, C., (2000), "A Cognitive Theory of Musical Meaning", Journal of Music Theory, Vol.44, No. 2: pp. 323-379.

Campbell, C., (2009), "The Violin Concerto Soloist's Orchestral Role, from Mozart to Beethoven", Performance practice review, Vol. 14, No. 1: pp. 1-21.

Hofstede, G. H., (2001), "Individualism and Collectivism", In: Hofstede, G. H. (ed.) Culture's consequences: comparing values, behaviors, institutions, and organizations across nations, SAGE, Oaks, Calif, 209-278.

Keefe, S. P., (2005), The Cambridge Companion to the Concerto, Cambridge University Press, Cambridge.

Monelle, R., (1992), Linguistics and Semiotics in Music, Harwood Academic, Chur, Switzerland.

Short, T. L., (2007), Peirce's Theory of Signs, Cambridge University Press, Cambridge.

Stevens, J. R., (1974), "Theme, Harmony, and Texture in Classic-Romantic Descriptions of Concerto FirstMovement Form", Journal of the American Musicological Society, Vol. 27, No. 1: pp. 25-60. 
Other sources:

Bhawuk, D. P. S., (2017), "Individualism and Collectivism", Wiley Online Library, [Online]. Available: https://onlinelibrary.wiley.com/doi/full/10.1002/9781118783665.ieicc0107, accessed 05.09.2020. at 19:15

Eisen, C., "The Classical period", In: Laura Macy (ed.), Grove Music Online, http://www. oxfordmusiconline. com/grovemusic, accessed 03.09.2020. at 18:20

Griffiths, P., "The 20th century.", in: Laura Macy (ed.), Grove Music Online, http://www.oxfordmusiconline. com/grovemusic, accessed 03.09.2020. at 15:05

Weber, W., "Concert (ii).", in: Laura Macy (ed.), Grove Music Online, http://www. oxfordmusiconline.com/ grovemusic, accessed 03.09.2020. at 15:05

Hutchings/r, A., Talbot, M., Eisen, C., Botstein, L., Griffiths, P., "Concerto", in: Laura Macy (ed.), Grove Music Online, http://www.oxfordmusiconline.com/grovemusic, accessed 11.05.2021. at 10:10

\section{RAZVOJ, FUNKCIJA I ZNAČENJE DIJALOGA SOLISTE I ORKESTRA U OKVIRU KONCERTA PRIKAZAN KROZ PIRSOVU TIPOLOGIJU ZNAKOVA}

Dihotomija između individualizma i kolektivizma, duboko ukorenjena u razvoju socijalnog života, odražava antropološki aspekt koji se reflektuje i na muzičku umetnost. Ova opozicija, koja se ispoljava kroz odnos soliste $i$ orkestra u okviru koncerta, jedna je od njegovih glavnih žanrovskih crta koja opstaje uprkos svim promenama koje su se odvijale kroz istoriju, ali koja je ipak podložna modifikacijama. Ipak, na ulogu ovih entiteta osim stila epohe uticao je i lični stil kompozitora, što se takođe mora uzeti u razmatranje prilikom sagledavanja dela sa bilo kog stanovišta. Predlog da se primeni metoda tipologije znakova Čarlsa Pirsa pomogao je rasvetljenju značenja koje ova vrsta dijaloga proizvodi i koja su hijerarhijski raspoređena i pozicionirana $u$ sklopu piramidalne strukture. Shodno tome, tema rada ima za cilj da prikaže odnos soliste $i$ orkestra, da prikaže kakva je njihova funkcija u okviru koncerta, kako su se njihove uloge menjale kroz smenu epoha u istoriji i kakvo značenje ova vrsta dijaloga proizvodi.

Ključne reči: koncert, solista, orkestar, dijalog, Pirsova Tipologija znakova 